\section{Lukewarm praise for effort}

\section{Washington}

A MODEST increase in the US research programme on the creation of sustained thermonuclear fusion by magnetic confinement is recommended in a report issued last week by the National Academy of Sciences* but, in recognition of the present political mood, the report also calls for efforts at international cooperation and the involvement of domestic industry in building the next round of machines.

Magnetic confinement devices aim to create the conditions for a continuous thermonuclear 'burn' by holding a plasma of deuterium-tritium fuel in a cocoon of strong magnetic fields at high enough density and temperature for fusion reactions to begin. But although experimental machines of increasing sophistication have been built since the $1950 \mathrm{~s}$, a sustained fusion reaction has not been achieved, and the present generation of 'tokamaks', represented by the Joint European Torus (JET) at Culham Laboratory in England and similar devices at

\section{GENETIC MEDICINE}

\section{Go-ahead for gene transfer experiment} Washington

AN experiment to insert foreign genes into humans started this week, following the settlement of a lawsuit brought by Jeremy Rifkin of the Foundation on Economic Trends. Under the terms of last week's settlement, the National Institutes of Health will alter the charter of the Recombinant DNA Advisory Committee (RAC) to make the approval process for gene transfer protocols more open and explicit.

W. French Anderson of the National Heart, Lung and Blood Institute and $\mathbf{R}$. Michael Blaese and Steven A. Rosenberg of the National Cancer Institute proposed their experiment last June. A special class of activated lymphocytes with antitumour properties will be marked with a bacterial gene and then reinjected into human cancer patients.

Last October, RAC approved the experiment, but did so without waiting for a decision about its appropriateness from a subcommittee specially formed to judge the scientific and ethical questions raised by the protocol. The altered charter requires that a subcommittee must vote on all proposals referred to it before they can be taken up by the parent committee.

If the subcommittee ignores the proposal, investigators can appeal their case to the full committee. And all votes must now be taken in public unless they may be legally held behind closed doors. Joe Palca

the Princeton Plasma Physics Laboratory (PPPL) in the United States and in Japan and the Soviet Union, will not achieve that goal.

Although all the countries with fusion programmes are pondering the next step, the prospects for international collaboration are complicated by disagreement over what experimental goal to attack. In the United States, plans are in hand for the Compact Ignition Tokamak (CIT), whose purpose is to persuade the hot plasma to ignite but not necessarily to create a sustained burn, whereas in Europe the Next European Torus (NET) is being contemplated as a machine which will hold a hotter, denser plasma for longer than JET, but in which actual ignition may still not occur. The next step for the Japanese programme is likely to be something similar to NET.

The total cost of any single fusion machine runs to hundreds of millions of dollars, and none of the contemplated next generation of machines has been approved for construction. CIT has been given $\$ 3.5$ million for continued research, but the US Congress, in its presently parsimonious mood, shows no signs of releasing enough money to start building. HYDROELECTRIC DAM

\section{London}

THE Hungarian government has declared a two-month moratorium on construction of the controversial Nagymaros hydroelectric dam, pending the report of yet another official commission of inquiry. Public opposition to the dam on environmental and social grounds has been increasing over the past two years, but until now the Hungarian government has maintained that, although in hindsight the scheme has to be considered a mistake, it would now cost too much to cancel it. Furthermore, the Nagymaros dam was designed to function in conjunction with one upstream at Gabcikovo in Czechoslovakia, and to withdraw unilaterally would constitute a breach of international contract. This latter point was stressed by Hungary's foreign minister Peter Varkonyi, a few weeks ago in a lecture at the Royal Institute of International Affairs in London. Soon after, however, Varkonyi was replaced as foreign minister by Gyula Horn, who has made it clear that he considers the agreement to halt construction the correct one.

The Czechoslovak government considers its part of the scheme, the Gabcikovo dam, to be vital to its future energy plans. Construction work at Gabcikovo is now virtually complete, but without the Nagymaros barrage to act as a trap, the Gabcikovo station will never be able to

\title{
Two-month moratorium
}

Informal international collaboration between the national fusion research programmes proceeds, according to Harold Furth, director of PPPL, at a 'furious' pace, with exchanges of personnel, information and experimental methods. But in 1987 the United States proposed a more formal collaboration between itself and Europe, Japan and the Soviet Union to design an International Thermonuclear Engineering Reactor (ITER), which would combine studies both of the physics of ignition and of the engineering issues of sustainability. A four-way work programme has begun at Garching, West Germany, but has not yet supplanted any of the countries' individual efforts.

The NAS report criticizes the US programme for its failure, compared to the efforts by the Japanese and the Europeans, to obtain industrial participation in the construction of fusion machines, especially as the ultimate goal is to produce a commercial energy-generating reactor. But although industrial participation and international collaboration are themes which carry individual political appeal, worries about technology transfer and foreign acquisition of US research results may prove a bigger political detraction.

David Lindley

* Pacing the magnetic fusion program. National Academy Press, 1989. operate at full strength. Last week, Foreign Ministry press secretary Ivan Kulhanek said that the agreement on the construction and operation of the dams is binding on both sides. The ecological considerations now being urged by the Hungarians, he said, had been studied in depth long before construction started and the Hungarian moratorium had been declared for "political" reasons.

The Czechoslovak party paper Rude Pravo was even more explicit. The Hungarian government, it said, had been pressurized by opposition groups, who had "manipulated" public opinion.

Hungary could also face difficulties with Austria if the Nagymaros dam is cancelled. At the end of 1984, the Austrian Greens forced the cancellation of plans for a hydroelectric station at Hainburg, and the Austrian government then undertook to bear a considerable part of the construction costs of Nagymaros, with eventual repayment in the form of electricity. If the dam is not completed, the Hungarians will have to reimburse the Austrians - as well as making good the environmental damage. The anti-dam campaigners have argued for years that cancellation would be cheap at the price. For the first time, there are indications that the Hungarian government may be beginning to share their view. 